\title{
A Study of Specificity of Cores for Group D Streptococci
}

\author{
By RUTH G. MCCANDLESS, T. J. HENSLEY, M. COHEN, \\ G. M. KALMANSON AND L. B. GUZE \\ Research and the Medical Service, Veterans Administration Hospital (Wadsworth), \\ Los Angeles, California 90073, the Department of Medicine, Harbor General \\ Hospital, Torrance, California 90509, and the Department of Medicine, UCLA \\ School of Medicine, Los Angeles, California 90024, U.S.A.
}

\section{(Accepted for publication 5 August 197I)}

\section{SUMMARY}

An electron microscopic study of strains of many serological groups of streptococci substantiates a previous suggestion that an intracellular structure, termed 'core', is a presumptive taxonomic indicator for group D streptococci.

\section{INTRODUCTION}

Cohen, McCandless, Kalmanson \& Guze (1968) first used the name 'core' for the long cylindrical organelles which occur in stable and unstable L-forms of Streptococcus faecalis G-K (ATCC 2324I ; $\left.\mathrm{B}_{14}\right)$. One kind of core was designated 'tubular' because its cylindrical outer shell consists of one to three thin, electron-dense layers; ribosome-like particles are distributed irregularly along the interior of the tubular core. The other kind of core was designated 'non-tubular' because it consists of a cylindrical matrix, with ribosome-like particles along the axis of the core. McCandless, Cohen, Kalmanson \& Guze (1968) showed that only non-tubular cores occur in the parent bacterial form of $S$. faecalis $\mathrm{G}-\mathrm{K}$ and in bacterial forms of other group D streptococci; they did not detect cores in streptococcal strains of serological groups A, B and C and of the viridans group, nor in single strains of Staphylococcus aureus, Escherichia coli and Bacillus megaterium. These limited observations of bacterial forms of streptococci led McCandless et al. (I968) to suggest that cores were possibly specific for group D streptococci.

The analysis by McCandless et al. (1968) of a few sets of serial sections of cells of Streptococcus faecalis G-K, fixed after $24 \mathrm{~h}$. of culture at $37^{\circ}$ in brain heart infusion broth (BHI), indicated that the majority of cells contained one core; most of the other cells lacked cores, and only rarely did a cell contain two cores. Cores ranged from 0.10 to $0.16 \mu \mathrm{m}$. in cylindrical diameter and were of such length and orientation as nearly to span the cell. On the basis of electron microscopical morphology and dimensions, McCandless et al. (1968) indicated the ways in which cores are clearly distinguishable from other reported linear bacterial organelles, such as rhapidosomes or microtubules, found in some genera of bacteria, and from the helical arrays of ribosome-like particles in some strains of Mycoplasma gallisepticum. Similarly, even the tubular cores in the stable and unstable L-forms of $S$. faecalis G-K grown in broth cultures are distinct in size and morphology from 'microtubular' structures described by Corfield \& Smith (1968) in penicillin-agar cultures of stable and unstable Lforms of certain group D streptococci: tubular cores do not exceed in number about ten per cell, contain ribosome-like particles, and either span the cell or are so long, up to about Io $\mu \mathrm{m}$., that the core extremities are surrounded by only thin sleeve-like cytoplasmic 
protrusions from the main cell body (Cohen et al. 1968); in contrast, in the micrographs of Corfield \& Smith (1968), intracellular 'microtubular' structures are hollow tubular invaginations of the cytoplasmic membrane of not more than about $0.2 \mu \mathrm{m}$. in length and can be very numerous in some cells.

McCandless et al. (I968) compared the appearances of cores after two different kinds of fixation for electron microscopy - one the osmium tetroxide procedure of Ryter \& Kellenberger (1958), the other a sequence of treatments with glutaraldehyde and osmium tetroxide fixatives. The latter method was more useful for detection and morphology of cores in sections because of higher electron microscopical image contrast. Cores have also been visualized by electron microscopy after freeze-etching of unfixed bacteria (Coleman \& Bleiweis, 1971) and by phase-contrast microscopy in presumably living L-forms of Streptococcus faecalis $\mathrm{G}-\mathrm{K}$ (Cohen et al. 1968). Although McCandless et al. (1968) reported cores to occur in the ATCC 9790 strain of S. faecalis grown in BHI, Higgins \& Shockman (1970) found cores to be absent when this strain was grown in synthetic medium. Cores disappear in $S$. faecalis $\mathrm{G}-\mathrm{K}$ within a few seconds after subinoculation from the stationary phase of growth in BHI and reappear in the post-logarithmic phase of growth (M. Cohen et al. unpublished data). Thus, because they have been visualized by a variety of microscopical techniques, because their presence or absence depends upon the culture medium used, because they disappear and reappear at different stages in the bacterial growth curve in BHI and because their presence in streptococci may be restricted to group D organisms, cores are evidently real structures and not artefacts of preparation.

The present communication reports observations on a number of additional group $\mathrm{D}$ strains and strains of streptococcal serological groups not previously examined for the presence of cores.

\section{METHODS}

Organisms. Sources of the streptococcal strains are listed in Table I. Several of these strains, each identified with a cell wall compositional pattern number according to the system of Colman \& Williams (I965), were obtained from Dr G. Colman. None of the other strains carried such pattern designations. That all strains considered to be group D streptococci belonged to this group was confirmed by group precipitin tests with Difco Bacto-Streptococcus Antiserum and with antigen extracts obtained by the autoclave method (Rantz \& Randall, 1955) or by a slight modification (Collins, 1967) of the formamide extraction technique (Fuller, 1938).

Culture conditions. All strains were grown in Difco Brain Heart Infusion broth (BHI) at $37^{\circ}$ and some also at $30^{\circ}$, particularly the group $\mathrm{N}$ strains which grew better in $24 \mathrm{~h}$. at this temperature.

Specimen preparation. Bacteria from cultures in the stationary phase (I 8 to $48 \mathrm{~h}$.) were prepared for electron microscopy by treatment at room temperature (about $22^{\circ}$ ) except where otherwise indicated. To $5 \mathrm{ml}$. culture was added, with mixing, $0.5 \mathrm{ml}$. $13.3 \%(\mathrm{w} / \mathrm{v})$ solution of biological grade glutaraldehyde either in distilled water (solution $\mathrm{pH}_{3} . \mathrm{I}$ to 3.5 ) or in $0.085 \mathrm{M}$-phosphate buffer (solution $\mathrm{pH} 7.3$ to 7.6 ). The mixture was centrifuged at oI $20 \boldsymbol{g}_{\max }$. for 50 min., the supernatant fraction removed by decanting and the sediment resuspended in the residual fluid. To this suspension were added, with mixing, $5 \mathrm{ml}$. I \% (w/v) $\mathrm{OsO}_{4}$ in $75 \%(\mathrm{v} / \mathrm{v})$ Michaelis (I93I) veronal-acetate buffer with $\mathrm{NaCl}(\mathrm{pH} 7 \cdot \mathrm{I}$ to $7 \cdot 4$ ). The suspension was placed in the dark for $30 \mathrm{~min}$., then centrifuged for $30 \mathrm{~min}$. The sediment was then resuspended in the residual fluid, after again decanting the supernatant fraction, and then embedded in molten $2 \%$ agar cooled to about $50^{\circ}$. Small agar blocks containing bacteria 
were dehydrated in ice-cold absolute ethanol for $10 \mathrm{~min}$., stained in ice-cold $\mathrm{UO}_{2}\left(\mathrm{CH}_{3} \mathrm{COO}\right)_{2}$ $.2 \mathrm{H}_{2} \mathrm{O}$ in absolute ethanol, I \% (w/v), for $30 \mathrm{~min}$., then dehydrated further in ice-cold absolute ethanol for $10 \mathrm{~min}$. and during the succeeding $50 \mathrm{~min}$. by three changes at room temperature of absolute ethanol which had been dried over molecular sieves. The agar blocks were then passed through propylene oxide for Epon embedment following the method of Luft (196I). Ultrathin sections on Formvar substrates, stained with alkaline lead citrate (Venable \& Coggeshall, 1965), were coated with carbon by vacuum evaporation. For every experiment, in order to make certain that the procedure used that day was capable of preserving core structure, an I8, 24 or $48 \mathrm{~h}$. culture of Streptococcus faecalis G-K was included as a control as cores were always evident in this strain.

Electron microscopy. Since the experimental purpose of this study was to determine those strains of streptococci with which cores are associated rather than to measure the frequency with which cores occur in populations of cells, sections were rapidly scanned by transmission electron microscopy, generally without photomicrography. This scanning approach was not only possible because of the ease with which cores can be detected and recognized as such in longitudinal and slightly oblique sectional views (McCandless et al. 1968), but was also practical because for 15 of 16 strains in which cores were observed the cores were quickly located under at least one incubation condition, presumably reflecting appreciable frequencies of occurrence of cores in the bacteria. (Cores viewed in a position nearer to cross section cannot yet be identified as cores with certainty except by analysis of micrographs of serial sections.) The samples of streptococcal strains in which cores were recorded as absent or rare were searched much more exhaustively (several hundreds of cells per incubation condition) than those samples of 15 strains in which cores were quickly found. When cores were observed in a strain, no further experiments were performed with that strain to determine whether cores would be present under other incubation conditions, except in the case of the control strain Streptococcus faecalis G-K.

\section{RESULTS AND DISCUSSION}

The results of the present study and those reported for streptococci by McCandless et al. (1968) are summarized in Table $\mathrm{I}$.

Cores were readily found in 15 of the 17 group D strains examined, were very rare in one group D strain (Streptococcus faecalis ATCC I2755) and were not found in the remaining group D strain (S. bovis ATCC I5352) nor in all the examined strains of other serological groups or of the viridans group. In S. faecalis ATCC I 2755 only one core was detected among 500 cells examined after $24 \mathrm{~h}$. of incubation at $37^{\circ}$ and none after 18,42 or $48 \mathrm{~h}$. of $37^{\circ}$ incubation; this strain is motile (American Type Culture Collection, 1968), but motility seems unrelated to the rare occurrence or absence of cores because cores were frequent in $S$. faecium subsp. mobilis ATCCI4432, a group D strain which is also motile (Langston, Gutierrez \& Bouma, 1960). Streptococcus bovis ATCC I 5352, the group D strain in which cores were not observed, is an ultraviolet-induced mutant strain of $S$. bovis ATCC 1535I (Niederman, Reichelt \& Wolin, I964), but cores were present in the latter parent strain. Obviously, if cores are not detected in a limited examination, it is not possible to say that they are always absent.

The significance of the original suggestion by McCandless et al. (1968) of a correlation between the presence of cores and group $\mathrm{D}$ antigenicity was in some doubt because streptococcal strains selected for study represented only serological groups A, B, C and D and the viridans group. This chance selection of serological groups, together with the finding of cores only in group D strains, did not permit at that time the evaluation of a possible 


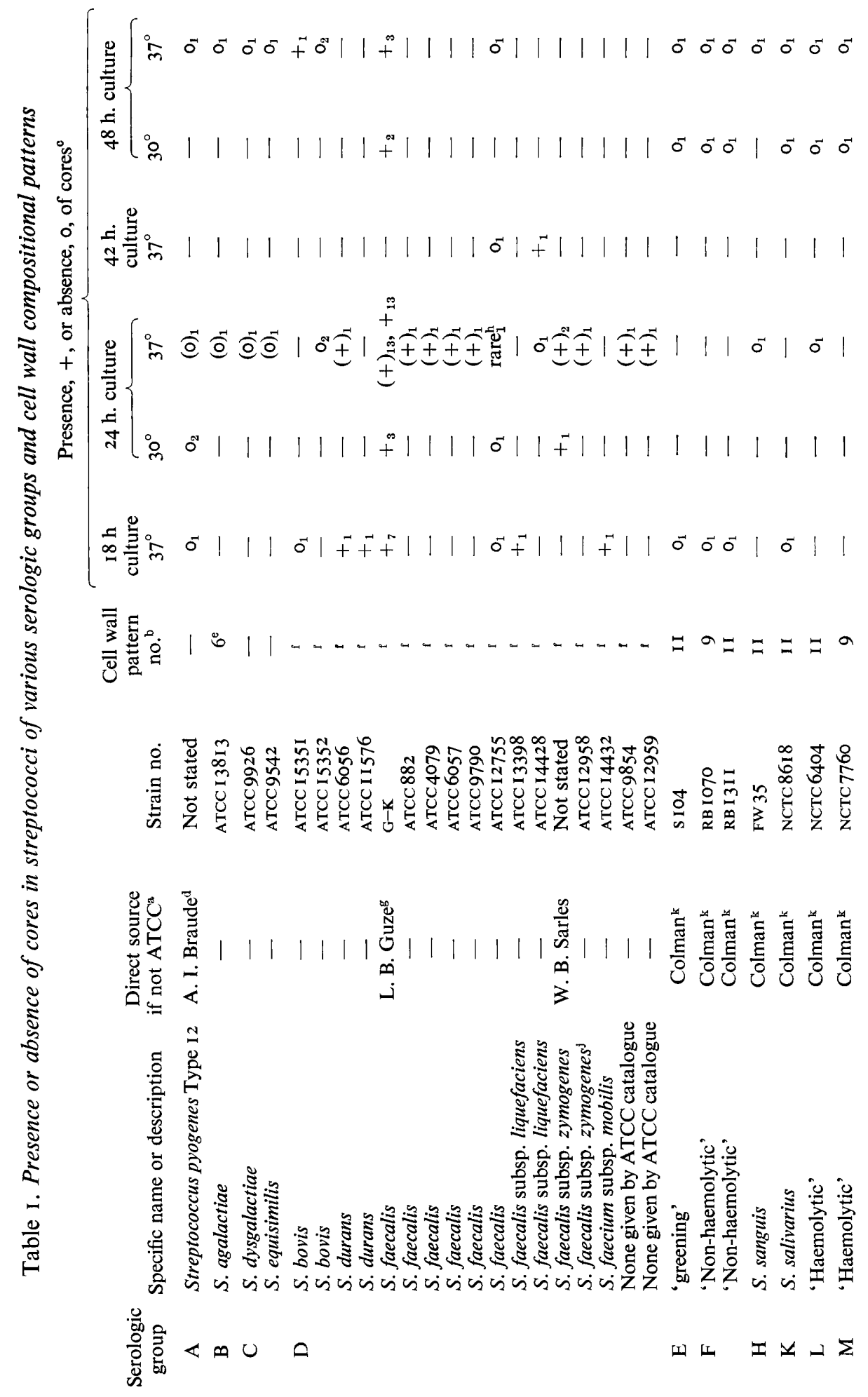


Specificity of cores for group D streptococci
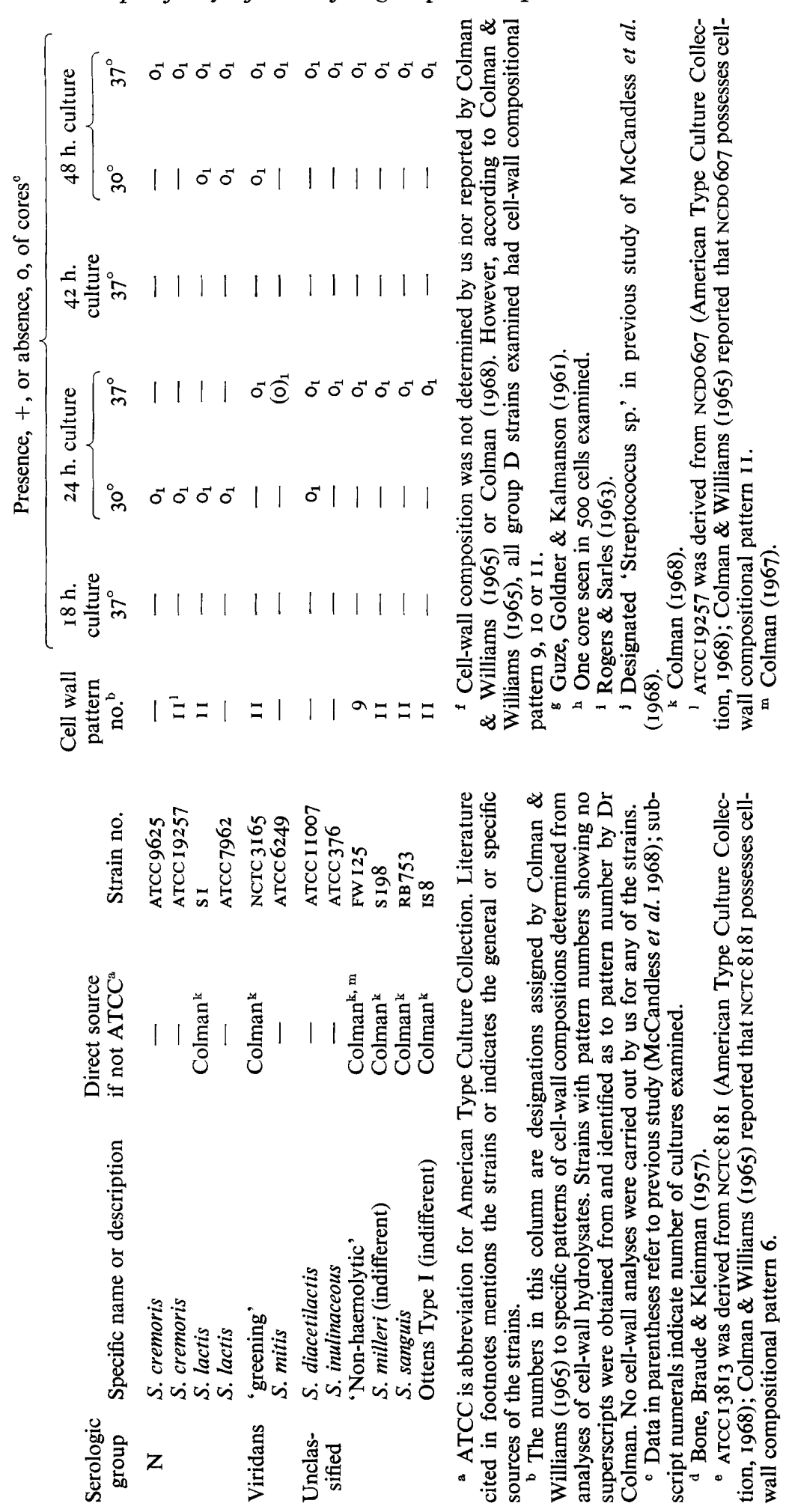
alternative correlation between the presence of cores and cell-wall composition. Colman \& Williams (I965) had distinguished 26 different patterns of cell-wall composition among I 97 strains of streptococci by means of paper chromatographic analyses of cell-wall hydrolysates. They reported that only patterns designated 9, I0 or I I occurred in the cell walls of the group D streptococci examined, whereas none of the strains in groups A, B and C had these cell-wall compositional patterns. Pattern Io was found by them only in some of the group D strains. On the other hand, they observed patterns 9 and I I not only in the remaining group D strains, as well as in some viridans strains, but also in strains of serological groups of streptococci not examined by McCandless et al. (I968) for the presence of cores. Thus, an important part of the present study was to determine whether cores occur in any streptococcal strains which are not group D organisms but which have cell walls with compositional patterns 9 or II. Table I shows that cores were not detected in any of I3 such strains examined.

Among the serological groups of streptococci, groups D and $\mathrm{N}$ are unusual in that their group specific antigens are apparently intracellular rather than in the cell wall (Elliott, 1959, 1963; Jones \& Shattock, I960; Smith \& Shattock, 1962, 1964). However, Table I indicates that the presence of cores does not necessarily correlate with that of intracellular group specific antigen. Although cores were detected in 16 out of 17 group D strains, no cores were found in any of the four group $\mathrm{N}$ strains examined.

The strong correlation established now between the presence of cores and that of group D specific antigen in streptococci, in the stationary phase of growth in BHI, invites further investigational interest. The group D antigens are intracellular teichoic acids (Elliott, I962; Wicken \& Baddiley, I963; Wicken, Elliott \& Baddiley, 1963) and are generally considered to be absent from the cell wall (Elliott, 1959; Jones \& Shattock, I960) and to be located in or on the cytoplasmic membrane (Hay, Wicken \& Baddiley, I963; Shattock \& Smith, 1963; Slade \& Shockman, 1963; Shockman \& Slade, 1964; Smith \& Shattock, 1964). The intracellular teichoic acids of other Gram-positive bacteria are similarly located (Baddiley, 1968), and, for this reason, such teichoic acids are now called 'membrane' teichoic acids (Archibald $\&$ Baddiley, I966). None of the published studies in which localizations of group D specific antigens have been attempted rules out the hypothesis of McCandless et al. (1968) 'that core matrix, or some part thereof, is group D antigen'.

In some of these published studies on localization of group D specific antigens, cores may be presumed to have been absent. Cores are absent in the logarithmic phase of growth in Streptococcus faecalis G-K (M. Cohen, unpublished), and so cores may also have been absent in the logarithmic phase group D streptococci sampled by Smith \& Shattock (I964) for localization of group D specific antigens. McCandless et al. (I968) reported cores in Streptococcus faecalis ATCC 9790 cultured in BHI; but in the localization studies of Slade \& Shockman (I963) and Shockman \& Slade (1964) a synthetic culture medium was used in which cells of this strain contain no cores, according to Higgins \& Shockman (1970). Cores disappear within a few seconds when stationary phase cultures of $S$. faecalis $\mathrm{G}-\mathrm{K}$ are subinoculated into fresh medium (M. Cohen, unpublished); thus, if cores happened to be present in the stationary phase culture of a group D streptococcus sampled by Hay et al. (I963) for localization of intracellular glycerol teichoic acid, then those cores could have disappeared during muramidase treatment of the cells to obtain for chemical analysis a cellwall hydrolysate and protoplasts. Shockman \& Slade (I964) suggested that such protoplasts may not have been completely stabilized against loss of antigen. Furthermore, assuming that cores were present in the group D streptococcus studied by Hay et al. (I963) and that the cores survived not only the lysis of cell walls and release of protoplasts, but also the subse- 
quent lysis of protoplasts by osmotic shock and centrifugal fractionation, then cores would probably have lodged in the protoplast membrane fraction, which contained a small part of the glycerol teichoic acid.

Since the two extremities of a core in situ are very close to the cytoplasmic membrane (McCandless et al. 1968) and since the cytoplasmic membrane in Gram-positive bacteria is the site of some of the enzymes which participate in the synthesis of membrane teichoic acid (Archibald \& Baddiley, I 966) it is conceivable that the core could, at the time of formation, incorporate some of this teichoic acid. Even in demonstrating the presence of protein and the absence of polysaccharide I,2-glycerol groups in cores, Coleman \& Bleiweis (I97I) indicated that 'partial composition by glycerol teichoic acids is not disproved...'. Whether or not cores in group D streptococci contain, in part, group D specific antigen awaits the isolation and chemical analysis of intact cores or a cytochemical staining of ultrathin sections of group D streptococci for the electron microscopical localization of group D specific antigen. The possibility should not be overlooked that such a peculiar organelle as the core may contain one or more core-specific, non-teichoic acid substances, which, in turn, could be specific for approximately the same streptococci presently classed serologically as group D.

In a recent study, Hubert $e$ t al. (197I) have shown that tubular and non-tubular cores, like those which occur in L-forms of Streptococcus faecalis G-K (Cohen et al. 1968), a Gram-positive bacterium, also occur in a stable L-form derived from a coreless bacterial form of Pseudomonas aeruginosa B I0490, a Gram-negative bacterium, and that the two species of L-forms are clearly distinguishable by means of fermentation reactions and sensitivities to antibiotics. If cores are not more widespread among bacteria and their L-forms than our limited survey and our inspection of electron microscopic literature have led us to believe, it is incredible that we should have encountered cores while investigating a stable L-form of a bacterium so different from group D streptococci as $P$. aeruginosa. Whether or not future study indicates that cores occur in any other Gram-positive and Gram-negative bacteria, and their $\mathrm{L}$-forms, the presence of cores in L-forms of both $S$. faecalis $\mathrm{G}-\mathrm{K}$ and $P$. aeruginosa в 10490 suggests either that the core is a very old organelle in terms of bacterial evolution, going back to some common ancestor of the Gram-positive and Gram-negative bacteria, or that the evolutionary development of cores occurred independently in these two categories of bacteria.

In view of the apparent absence of teichoic acids in Gram-negative bacteria (Heptinstall, Archibald \& Baddiley, 1970) and the occurrence of cores in an L-form of a Gram-negative bacterium, the hypothesis of McCandless et al. (I968) that some of the group D specific antigen in group $\mathrm{D}$ streptococci is present in cores may seem unreasonable. However, some of the chemical similarities between teichoic acids and lipopolysaccharides (Heptinstall et al. 1970) suggest that cell-wall lipopolysaccharides in Gram-negative bacteria may be antigenic and functional counterparts of teichoic acids in the Gram-positive bacteria. Furthermore, if in Pseudomonas aeruginosa в 10490 some of the chemical precursors for core formation were utilized exclusively for cell-wall synthesis, possibly cell-wall lipopolysaccharide synthesis, then this could account for a lack of cores in the bacterial form of this strain. Because the biology, biochemistry and range of distribution of cores in Gram-negative and Grampositive bacteria are unknown, it would be premature, therefore, to abandon the hypothesis that some group D specific antigen exists in cores of group D streptococci.

Because it is evident that the presence of cores in an unidentified stable L-form cannot, alone, indicate the kind of parent bacterial form from which it was derived, the presence of cores can now be considered only characteristic of group D among the streptococci. 
This research was supported in part by U.S. Public Health Service Grant no. AI-02257 and AI-033Io. We thank Dr G. Colman for the supply of strains, Doris M. Harter for preparing the great many cultures used and for conducting the culture incubation temperature trials required before some strains could be grown successfully, Diane V. Ward for performance of precipitin tests, and Earl G. Hubert for valuable advice.

\section{REFERENCES}

American Type Culture Collection (I968). The American Type Culture Collection Catalogue of Strains, 8th edn. Rockville, Maryland.

Archibald, A. R. \& Baddiley, J. (1966). The teichoic acids. Advances in Carbohydrate Chemistry 21, 323375.

BADDILEy, J. (1968). Teichoic acids and the molecular structure of bacterial walls. Proceedings of the Royal Society B r7o, 33I-348.

Bone, M., Braude, A. I. \& Kleinman, H. (I957). Complement-fixing antibody response to M-protein of nephritogenic streptococci in glomerulonephritis. Journal of Laboratory and Clinical Medicine 50, 705$7 \mathrm{II}$.

Cohen, M., McCandless, R. G., Kalmanson, G. M. \& Guze, L. B. (I968). Core-like structures in transitional and protoplast forms of Streptococcus faecalis. In Microbial Protoplasts, Spheroplasts and L-Forms, pp. 94-109. Edited by L. B. Guze. Baltimore: Williams \& Wilkins.

Coleman, S. E. \& Bleiweis, A. S. (I97I). Cytochemistry of core-like structures in group D streptococci. Bacteriological Proceedings 197 I, Abstract G r5o, 48.

Collins, C. H. (1967). Microbiological Methods, 2nd edn, pp. 259-260. New York: Plenum Press.

Colman, G. (1967). Aerococcus-like organisms isolated from human infections. Journal of Clinical Pathology 20, 294-297.

Colman, G. (I968). The application of computers to the classification of streptococci. Journal of General Microbiology 50, I49-158.

Colman, G. \& Williams, R. E. O. (I965). The cell walls of streptococci. Journal of General Microbiology 4r, $375-387$.

Corfield, P. S. \& SMITh, D. G. (1968). Microtubular structures in group D streptococcal L-forms. Archiv für Mikrobiologie 63, 356-361.

ELliotT, S. D. (1959). Group and type-specific polysaccharides of group D streptococci. Nature, London $\mathbf{1 8 4}$, I342.

ElliotT, S. D. (1962). Teichoic acid and the group antigen of group D streptococci. Nature, London $\mathbf{1 9 3}$, I I05-I 106.

ElljotT, S. D. (1963). Teichoic acid and the group antigen of lactic streptococci (group N). Nature, London 200, II 84-II 85 .

FULLER, A. T. (1938). The formamide method for the extraction of polysaccharides from haemolytic streptococci. British Journal of Experimental Pathology r9, I30-I39.

Guze, L. B., Goldner, B. H. \& Kalmanson, G. M. (I96I). Pyelonephritis. I. Observations on the course of chronic non-obstructed enterococcal infection in the kidney of the rat. Yale Journal of Biology and Medicine 33, 372-385.

Hay, J. B., Wicken, A. J. \& BadDiley, J. (1963). The location of intracellular teichoic acids. Biochimica et biophysica acta 7I, I88-190.

Heptinstall, S., Archibald, A. R. \& Baddiley, J. (1970). Teichoic acids and membrane function in bacteria. Nature, London 225, 519-521.

Higgins, M. L. \& Shockman, G. D. (I970). Early changes in the ultrastructure of Streptococcus faecalis after amino acid starvation. Journal of Bacteriology 103, 244-254.

Hubert, E. G., Potter, C. S., Hensley, T. J., Cohen, M., Kalmanson, G. M. \& Guze, L. B. (I97I). Observations on L-forms of Pseudomonas aeruginosa. Infection and Immunity 4, 60-72.

Jones, D. \& ShatTock, P. M. F. (1960). The location of the group antigen of group D streptococcus. Journal of General Microbiology 23, 335-343.

Langston, C. W., Gutierrez, J. \& Bouma, C. (1960). Motile enterococci (Streptococcus faecium var. mobilis var. n.) isolated from grass silage. Journal of Bacteriology 8o, 714-718.

LUFT, J. H. (196I). Improvements in epoxy resin embedding methods. Journal of Biophysical and Biochemical Cytology 9, 409-4I4. 
McCandless, R. G., Cohen, M., Kalmanson, G. M. \& Guze, L. B. (I968). Cores, microbial organelles possibly specific to group D streptococci. Journal of Bacteriology 96, I400-I4I 2.

Michaelis, L. (1931). Der Acetat-Veronal Buffer. Biochemische Zeitschrift 234, I39-14I.

Niederman, R. A., Reichelt, E. C. \& Wolin, M. J. (I964). Microbiological assay for L-asparagine with a Streptococcus bovis mutant. Analytical Biochemistry 7, 379-382.

RANTZ, L. A. \& RANDALL, E. (I955). Use of autoclaved extracts of hemolytic streptococci for serological grouping. Stanford Medical Bulletin r3, 290-29I.

Rogers, C. G. \& SARLES, W. B. (I963). Characterization of enterococcus bacteriophages from the small intestine of the rat. Journal of Bacteriology 85, 1378-1385.

Ryter, A. \& Kellenberger, E. (1958). Étude au microscope électronique de plasmas contenant de l'acide désoxyribonucléique. I. Les nucléoides des bactéries en croissance active. Zeitschrift für Naturforschung $13 \mathrm{~b}, 597-605,600 a-600 \mathrm{~g}$.

Shatтock, P. M. F. \& SMIth, D. G. (1963). The location of the group D antigen in a strain of Streptococcus faecalis var. liquefaciens. Journal of General Microbiology 3r, iv.

Shockman, G. D. \& SLADE, H. D. (1964). The cellular location of the streptococcal group D antigen. Journal of General Microbiology 37, 297-305.

Slade, H. D. \& Shockman, G. D. (1963). The protoplast membrane and the group D antigen of Streptococcus faecalis. Iowa State Journal of Science 38, 83-96.

Sмiтн, D. G. \& Shatтоск, P. M. F. (I962). The serological grouping of Streptococcus equinus. Journal of General Microbiology 29, 73I-736.

Sмiтh, D. G. \& Shatтock, P. M. F. (1964). The cellular location of antigens in streptococci of groups D, N and Q. Journal of General Microbiology 34, $165-175$.

Venable, J. H. \& Coggeshall, R. (I965). A simplified lead citrate stain for use in electron microscopy. Journal of Cell Biology 25 (Part I of 2), 407-408.

Wicken, A. J. \& BADdiley, J. (I963). Structure of intracellular teichoic acids from group D streptococci. Biochemical Journal 87, 54-62.

Wicken, A. J., Elliott, S. D. \& Baddiley, J. (1963). The identity of streptococcal group D antigen with teichoic acid. Journal of General Microbiology 3I, 23I-239. 